\title{
FOUNDATION FOR DEVELOPMENT OF LINE-UP OF NATIVE DRY-CARGO VESSELS
}

\author{
ОСНОВАНИЯ ДЛЯ РАЗВИТИЯ ЛИНЕЙКИ \\ ОТЕЧЕСТВЕННЫХ СУХОГРУЗНЫХ СУДОВ
}

\section{ПІДСТАВИ ДЛЯ РОЗВИТКУ ЛІНІЙКИ ВІТЧИЗНЯНИХ СУХОВАНТАЖНИХ СУДЕН}

\author{
Gennadiy V. Egorov \\ egorov@meb.com.ua \\ ORCID: 0000-0003-2594-5273
}

Alexander G. Egorov

egorovag@meb.com.ua

ORCID: 0000-0002-2050-8640

\author{
Г. В. Егоров, \\ докт. техн. наук, профессор, ген. директор
}

А. Г. Егоров,

канд. техн. наук, с. н. с.

\author{
Marine Engineering Bureau, Odesa \\ Морское Инженерное Бюро, г. Одесса \\ Морське Інженерне Бюро, м. Одеса
}

\begin{abstract}
Purpose. Description of the methodology for medium term prediction of fleet composition. Methodology. Methods of ship theory and design, as well as ship structural mechanics, analysis and statistics are applied. Results. Forecast is given for the fleet composition and its structure until 2030, including ships built in XXI century, with taking into account ships ordered in 2020-2022. Scientific novelty. For the first time, systematic studies of the technical condition of river-sea dry-cargo vessels, including vessels built in the last twenty years, have been carried out. Practical impact. Special studies were carried out with 1735 dry-cargo vessels built from 1956 to 2000. The analysis has shown, as of April 2020, from all vessels 831 units are operating with an average age of 39.8 years. 766 vessels (44\%) were written off, of which 95 (12\%) were lost in accidents with an average age of 31.2 years and 671 were scrapped with an average age of delivery on metal 36.5 years. There are 138 vessels out of operation with an average age of 44.2 years. Today, there are about 1052 dry-cargo vessels in operation, of which $79 \%$ are "old", remaining $21 \%$ were built in XXI century. Since 2000, 221 river, river-sea and restricted area dry-cargo vessels have been built (or bought on the market). It is shown that the main factor determining the parameters of cargo vessels in water transport is the cargo base. Dry-cargo vessels of "Dnipro / Volgo-Don max" class were and remain the most in demand. It has been established that it is possible to reduce lightweight of ship only due to modern materials. An innovation is the use of new Al-Mg alloys with reduced scandium content. Due to the increase in strength, the mass of structures can be reduced compared to conventional aluminum alloys by $25 \%$. For river and river-sea cargo vessels use of composites for hatch covers (this solution is used in US water transport), movable transverse bulkheads, fittings and superstructure elements are actual. Key words: river-sea dry-cargo vessels; sailing area; condition; modeling; prognosis.
\end{abstract}

Анотація. Мета. Опис методики, яка дає змогу спрогнозувати склад флоту на середньострокову перспективу. Методика. Застосовано методи теорії і проєктування корабля, а також будівельної механіки корабля, аналізу і статистики. Результати. Поданий прогноз за складом флоту і його структурою до 2030 року, включаючи судна, побудовані в XXI столітті, з урахуванням суден, що були замовлені в 2020-2022 роках. Наукова новизна. Вперше виконано системні дослідження технічного стану суховантажних суден змішаного обмеженого району плавання, включаючи судна, побудовані в останні двадцять років. Практична значимість. Проведено спеціальні дослідження по 1735 побудованих із 1956 по 2000 роки суховантажних суден. Аналіз показав, що із цих суден за станом на квітень 2020 року працює 831 одиниця середнім віком 39,8 років. Списано 766 суден (44\%), із них втрачено в катастрофах 95 (12\%) середнім віком 31,2 роки і утилізовано 671 середнім віком здачі на металом 36,5 років. У відстої 138 суден із середнім віком 44,2 роки. Нині в роботі приблизно 1052 судна, з них «старих» 79\%, решта 21\% побудовані в XXI столітті. 32000 року побудовано (або куплено з ринку) 221 суховантажне 
судно змішаного, внутрішнього і морського обмеженого району плавання. Показано, що головним фактором, що визначає параметри вантажних суден водного транспорту, є вантажна база. Найбільш затребуваними були і залишаються суховантажні судна «Дніпро / Волго-Дон макс» класу. Встановлено, що зменшити масу судна в порожньому стані можна вже тільки за рахунок більш легких матеріалів. Нововведенням $є$ застосування нових Al-Mg сплавів зі зниженим вмістом скандію. Шляхом зростання міцності маса конструкцій може бути знижена порівняно зі звичайними алюмінієвими сплавами приблизно на 25\%. Для вантажних суден змішаного ріка-море плавання і річкового плавання актуальним є застосування композитів для виготовлення люкових закриттів (таке рішення застосовується на водному транспорті США), поперечних рухомих переділок, дільних речей, елементів надбудови.

Ключові слова: суховантажне судно змішаного плавання; район плавання; стан; моделювання; прогноз.

Аннотация. Цель. Описание методики, позволяющей спрогнозировать состав флота на среднесрочную перспективу. Методика. Применены методы теории и проектирования корабля, а также строительной механики корабля, анализа и статистики. Результаты. Дан прогноз по составу флота и его структуре до 2030 года, включая суда, построенные в XXI веком, с учетом судов, заказанных в 2020-2022 годах. Научная новизна. Впервые выполнены системные исследования технического состояния сухогрузных судов смешанного ограниченного района плавания, включая суда, построенные в последние двадцать лет. Практическое значение. Проведены специальные исследования по 1735 построенным с 1956 по 2000 год сухогрузным судам. Сегодня в работе примерно 1052 сухогрузов, из них «старых» 79\%, остальные 21\% построены в XXI веке. С 2000 года построено (или куплено на рынке) 221 сухогрузное судно смешанного, внутреннего и морского ограниченного района плавания. Показано, что главным фактором, определяющим параметры грузовых судов водного транспорта, является грузовая база. Наиболее востребованными были и остаются сухогрузные суда «Днепро / Волго-Дон макс» класса. Установлено, что уменьшить массу судна порожнем можно уже только за счет более легких материалов.

Ключевые слова: сухогрузное судно смешанного плавания; район плавания; состояние; моделирование; прогноз.

\section{ПОСТАНОВКА ЗАДАЧИ}

Значительную часть мирового торгового флота составляют суда дедвейтом менее 5000 тонн. Они, как правило, осуществляют перевозки между морскими, устьевыми и речными портами. Их значительная часть имеет ограничения по районам, сезонам, удаленности от места убежища, условиям волнения и ветра, т.е. относится к судам ограниченного района плавания (СОРП). Наличие таких ограничений позволило существенно уменьшить строительную стоимость СОРП за счет обоснованного снижения требований к общей и местной прочности, мореходным качествам корпусов, номенклатуре и параметрам судового оборудования и снабжения, мощности главных двигателей, что позволило увеличить грузоподъемность судов при фиксированных проходных осадках за счет уменьшения массы судна порожнем и роста коэффициента общей полноты [1].

Особенностью отечественных СОРП является то, что они были разработаны на основе судов внутреннего плавания (СВВП). К началу 60 -х годов усилиями советских конструкторов был создан новый архитектурно-конструктивный тип СВВП с «ящичными» трюмами, широким раскрытием палубы, практически без «карманов», с двойным дном и двойными бортами, с малой осадкой. Аналогичные суда на море появились позже. При этом реальный дедвейт (в море) у таких судов вырос до 8000 тонн.

При проведении анализа такого флота следует четко понимать, что главным его признаком являет- ся именно грузовая база, так как флаг у судна в данный конкретный момент может быть самым разным, часто в зависимости от того грузопотока, на который его нацеливает частный судовладелец, - надо будет работать с речных портов, флаг будет российский или украинский, с морских портов (включая Ростов-наДону, Санкт-Петербург, Архангельск, Астрахань, Херсон и другие де-факто по путевым условиям речные, но юридически - морские порты) возможны самые различные варианты [7].

Реальный интерес отечественного судоходного бизнеса сегодня сосредоточен в нескольких главных направлениях:

- перевозка грузов из(в) мелководных и устьевых портов на морские порты;

- работа на рейдовые перевалочные комплексы;

- перевозка по внутренним водным путям, в том числе на морские порты, с выходом в море (классическая перевозка смешанного река-море плавания);

- «северный» завоз;

- транзит через внутренние водные пути в (из) Каспийское море, а также мелкопартионные (от 2000 до 8000 тонн) перевозки между морскими портами.

Эти СОРП в силу особых путевых условий сильно отличаются от мирового флота. Парадокс состоит в том, что на открытом морском рынке этим судам делать нечего (они не смогут быть конкурентоспособными с судами существенно большего размера - хендисайзами, панамаксами, суэцмаксами, кэпсайзами) - это эффект размера (5000-7000 тонн про- 


\section{СУДНОБУДУВАННЯ № 3 - 2020}

тив 50 000-300 000 тонн груза). Но и, наоборот, на мировом рынке нет морских судов, которые могли бы «заместить» суда смешанного река-море флота.

Для сведений, и речные суда из Европы тоже не могут быть конкурентоспособными на водном рынке России, Украины и Азербайджана - опять же из-за эффекта размера (типовая грузоподъемность европейского судна смешанного река-море плавания - 1700-2500 тонн против наших 5000-7000 тонн), а европейские СОРП плавания имеют дедвейты около 4500 тонн при осадке 5-6 м (предел портов на Азовском и Каспийском море - 4,5 м).

Именно в этом и состоит особенность флота большинства постсоветских компаний. Основу торгового флота в исследуемом сегменте составляют, в первую очередь, сухогрузные суда смешанного река-море плавания (ССП) и СОРП, а также морские суда с дедвейтом до 8000 тонн (называемые «коастерами»). Этот флот состоит из двух больших групп: грузовых самоходных судов смешанного, внутреннего и ограниченного морского плавания самых известных «советских» серий, построенных с 1956 по 2000 годы, и новых судов новых проектов, построенных уже в XXI веке.

\section{АНАЛИЗ ПОСЛЕДНИХ ИССЛЕДОВАНИЙ И ПУБЛИКАЦИЙ И ВЫДЕЛЕНИЕ НЕ РЕШЕННЫХ РАНЕЕ ЧАСТЕЙ ОБЩЕЙ ПРОБЛЕМЫ}

В литературе отсутствуют системные исследования технического состояния сухогрузных судов смешанного плавания, работающих на отечественном рынке, с оценкой и прогнозом по составу на среднесрочную перспективу.

Суда речного, смешанного и ограниченного морского района плавания составляют основу флота судов, работающего в отечественных портах, поэтому крайне важным является получить прогноз по составу этого флота до 2030 года.

\section{ЦЕЛЬ И ЗАДАЧИ ИССЛЕДОВАНИЯ}

Целью исследования является описание методики, позволяющей спрогнозировать состав флота на среднесрочную перспективу.

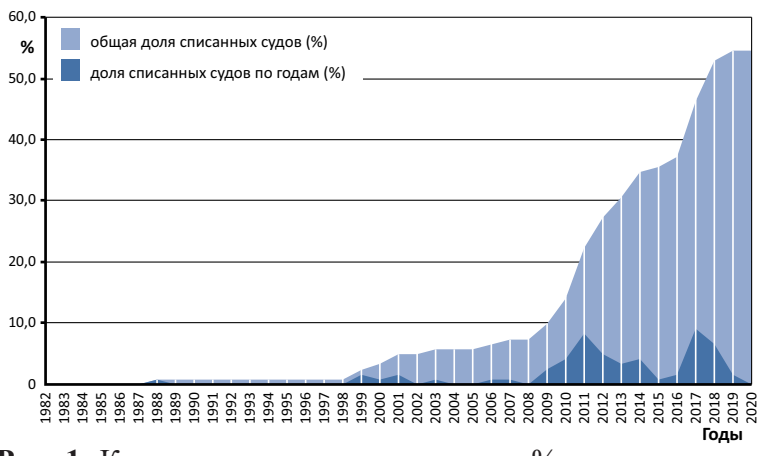

Рис. 1. Количество списанных судов в \% соотношении от всех судов проекта 1557 типа «Сормовский»

\section{МЕТОДЫ, ОБЪЕКТ И ПРЕДМЕТ ИССЛЕДОВАНИЯ}

Применялись методы теории и проектирования корабля, а также строительной механики корабля, анализа и статистики. Объект - сухогрузные суда ограниченного района плавания. Предмет - состояние корпуса, устройств и механизмов сухогрузных судов, характеристики существующих и перспективных сухогрузных судов.

\section{ОСНОВНОЙ МАТЕРИАЛ}

Авторами были проведены специальные исследования (начатые еще в 2017 году [4]) по 1735 построенным с 1956 по 2000 годы сухогрузным судам (см. таблицу 1). Анализ показал, что из этих судов по состоянию на апрель 2020 года работает 831 единица средним возрастом 39,8 года. Списано 766 судов (44\%), из них потеряно в катастрофах 95 (12\%) средним возрастом 31,2 года и утилизировано 671 средним возрастом сдачи на металлом 36,5 года. В отстое 138 судов со средним возрастом 44,2 года.

Например, из 121 «Сормовских» проекта 1557 типа (строились в 1967-1986 годах) списаны $54,4 \%$ - 66 (17\% - 11 судов потеряны в катастрофах, утилизировано 55 судов). В эксплуатации 47 судов средним возрастом 41,2 года. Средний возраст утилизации - 39,4 года. Основной график списания судов (см. рис. 1 и 2) имеет после 2008 года ярко выраженный экспоненциальный характер (в 2011 году было утилизировано 10 судов), утилизация продолжается, например, в 2017-2019 годах было списано 21 судно. В отстое находится 8 судов средним возрастом 45,1 года - они, вероятнее всего, также будут сданы на металлолом.

Из 152 других не менее известных «трехтысячников» «Волго-Балтов» проектов 2-95 и 2-95A/R постройки ЧССР (строились в 1967-1984 годах) списаны 45,4\% - 69 (16\% - 11 судов потеряны в катастрофах, утилизировано 58 судов). В эксплуатации 79 судов средним возрастом 43,1 года, в отстое 4 судна средним возрастом 46 лет. Средний возраст утилизации - 41,1 год. Основной график списания судов имеет после 2008 года (см. рис. 3 и 4) ярко выраженный экспоненциальный характер - это отражение морального

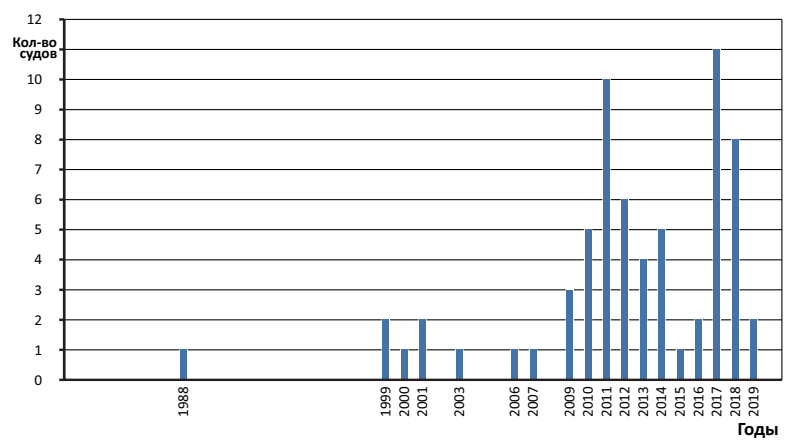

Рис. 2. Количество утилизированных судов проекта 1557 с распределением по годам 
Таблица 1. Сводная информация по составу флота сухогрузных судов смешанного плавания основных «классических» проектов

\begin{tabular}{|c|c|c|c|c|c|c|c|c|c|c|}
\hline \multirow[b]{2}{*}{ Проект } & \multirow[b]{2}{*}{ 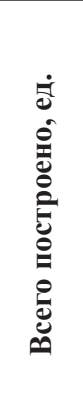 } & \multirow[b]{2}{*}{ 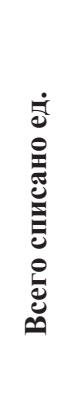 } & \multicolumn{2}{|c|}{$\begin{array}{c}\text { Всего списано, } \\
\text { ед. }\end{array}$} & \multirow[b]{2}{*}{$\begin{array}{l}\dot{0} \\
0 \\
8 \\
0 \\
0 \\
0 \\
0\end{array}$} & \multirow[b]{2}{*}{ 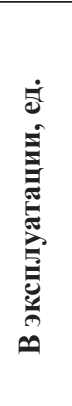 } & \multirow[b]{2}{*}{ 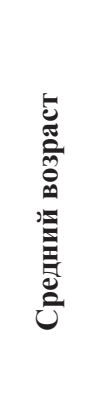 } & \multirow[b]{2}{*}{ 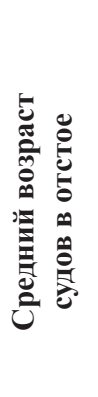 } & \multirow[b]{2}{*}{ 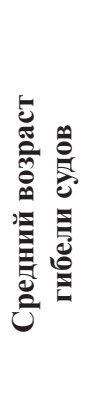 } & \multirow[b]{2}{*}{ 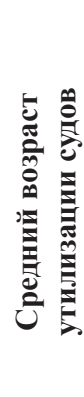 } \\
\hline & & & 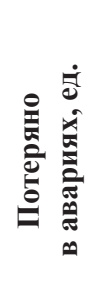 & 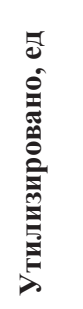 & & & & & & \\
\hline \multicolumn{11}{|c|}{ «Волго-Дон максы» } \\
\hline $507 \mathrm{~A}$, Б & 119 & 53 & 4 & 49 & 13 & 53 & 45,64 & 46,00 & 33,50 & 37,04 \\
\hline 1565 & 108 & 22 & 5 & 17 & 16 & 70 & 42,43 & 44,50 & 28,40 & 37,65 \\
\hline 05074 & 63 & 9 & 2 & 7 & 4 & 50 & 30,54 & 29,75 & 18,50 & 19,71 \\
\hline 19610,19611 & 47 & 0 & 0 & 0 & 4 & 43 & 27,05 & 25,50 & - & - \\
\hline Итого по разделу & 337 & 84 & 11 & 73 & 37 & 216 & 37,40 & 41,38 & 28,45 & 35,52 \\
\hline \multicolumn{11}{|c|}{ «Трехтысячники» } \\
\hline $92-040$ & 44 & 6 & 4 & 2 & 4 & 34 & 32,03 & 32,50 & 29,00 & 30,00 \\
\hline 791 & 40 & 37 & 7 & 30 & 0 & 3 & 53,67 & - & 32,57 & 34,73 \\
\hline $2-95$ & 152 & 69 & 11 & 58 & 4 & 79 & 43,16 & 46,00 & 34,64 & 41,05 \\
\hline 1557 & 121 & 66 & 11 & 55 & 8 & 47 & 41,21 & 45,13 & 35,82 & 39,35 \\
\hline 488 & 34 & 0 & 0 & 0 & 0 & 34 & 35,62 & - & - & - \\
\hline $1743,1743.1$ & 138 & 18 & 8 & 10 & 5 & 115 & 36,11 & 39,00 & 27,88 & 31,50 \\
\hline 16290,16291 & 10 & 0 & 0 & 0 & 0 & 10 & 24,70 & - & - & - \\
\hline 292,0225 & 33 & 2 & 0 & 2 & 1 & 30 & 38,90 & 38,00 & -- & 23,00 \\
\hline 17310 & 8 & 0 & 0 & 0 & 0 & 8 & 21,88 & - & - & - \\
\hline Итого по разделу & 580 & 198 & 41 & 157 & 22 & 360 & 37,64 & 41,27 & 32,73 & 38,27 \\
\hline \multicolumn{11}{|c|}{ «Первые» серии } \\
\hline $21-88,21-89$ & 118 & 58 & 12 & 46 & 13 & 47 & 55,51 & 54,54 & 36,00 & 37,50 \\
\hline 576 & 252 & 180 & 5 & 175 & 22 & 50 & 58,98 & 58,77 & 43,80 & 38,71 \\
\hline Фин1000 & 20 & 5 & 0 & 5 & 1 & 14 & 57,07 & 55,00 & -- & 42,40 \\
\hline Итого по разделу & 390 & 243 & 17 & 226 & 36 & 111 & 57,27 & 57,14 & 38,29 & 38,54 \\
\hline \multicolumn{11}{|c|}{ Морские ограниченного района плавания } \\
\hline 1588 & 24 & 21 & 3 & 18 & 0 & 3 & 32,67 & -- & 22,67 & 30,56 \\
\hline 16510 & 3 & 0 & 0 & 0 & 0 & 3 & 22,00 & -- & -- & -- \\
\hline 1572 & 35 & 24 & 1 & 23 & 8 & 3 & 43,67 & 43,88 & 37,00 & 36,78 \\
\hline Итого по разделу & 62 & 45 & 4 & 41 & 8 & 9 & 32,78 & 43,88 & 26,25 & 34,05 \\
\hline \multicolumn{11}{|c|}{ «Двухтысячники» } \\
\hline 613,620 & 16 & 7 & 0 & 7 & 1 & 8 & 41,25 & 39,00 & -- & 34,14 \\
\hline 781, 781Э & 76 & 70 & 7 & 63 & 2 & 4 & 55,50 & 54,50 & 31,14 & 37,21 \\
\hline $285,289,787$ & 27 & 20 & 0 & 20 & 4 & 3 & 34,67 & 31,50 & -- & 34,15 \\
\hline 1810двт, 1814двт & 22 & 20 & 1 & 19 & 2 & 0 & -- & 51,50 & 38,00 & 40,63 \\
\hline Итого по разделу & 141 & 117 & 8 & 109 & 9 & 15 & 43,73 & 41,89 & 32,00 & 37,05 \\
\hline \multicolumn{11}{|c|}{ СТ и СТК (в Укрречфлоте типа «Днепровец» и «Таврия») } \\
\hline 037 & 9 & 8 & 2 & 6 & 0 & 1 & 38,00 & -- & 28,50 & 29,17 \\
\hline $326,326.1$ & 67 & 24 & 2 & 22 & 8 & 35 & 35,09 & 37,00 & 20,00 & 30,00 \\
\hline 191, P-168, 19620, 19621 & 87 & 31 & 7 & 24 & 15 & 41 & 32,02 & 32,20 & 21,29 & 25,71 \\
\hline Итого по разделу & 163 & 63 & 11 & 52 & 23 & 77 & 33,49 & 33,87 & 22,36 & 27,92 \\
\hline \multicolumn{11}{|c|}{ Площадки и бункерные без крышек } \\
\hline Д-080, Д-080МК & 22 & 12 & 1 & 11 & 3 & 7 & 32,29 & 30,00 & 23,00 & 22,55 \\
\hline P-32, P-32A, P-32K & 40 & 4 & 2 & 2 & 0 & 36 & 37,50 & -- & 14,50 & 21,50 \\
\hline Итого по разделу & 62 & 16 & 3 & 13 & 3 & 43 & 36,65 & 30,00 & 17,33 & 22,38 \\
\hline Итого по типу & 1735 & 766 & 95 & 671 & 138 & 831 & 39,80 & 44,15 & 31,21 & 36,50 \\
\hline
\end{tabular}


старения по экономическим причинам (в 2011 году было утилизировано 9 судов, в 2010 году -8 судов). Утилизация продолжается, например, в $2017-$ 2020 годах было списано 16 судов.

Из 87 относительно новых судов - «овощевозов» проектов 19620, Р-168, 191 типа «СТ / Днепровец» (строились в 1983-1994 годах) списаны 35,6\% 31 (23\% - 7 судов потеряны в катастрофах, утилизировано - 24 судов, причем 20 имели флаг, отличный от России). В эксплуатации 41 судно средним возрастом 32 года. Средний возраст утилизации - 25,7 года. Основной график списания судов (см. рис. 5 и 6) также имеет после 2003 года ярко выраженный экспоненциальный характер, утилизация продолжается. В отстое находится 14 судов средним возрастом 30 лет - они, скорее всего, также будут сданы на металлолом, причем именно по не востребованности на рынке.

Похожая ситуация с 67 тоже относительно «свежими» судами постройки ГДР проектов 326 и 326.1 типа «СТК / Таврия» (строились в 1978-1989 годах). Из них списаны 35,8\% - 24 (8,6\% - 2 судов потеряны в катастрофах, утилизировано 22 судна). В эксплуатации 35 судов средним возрастом 35,1 года. Средний возраст утилизации - 30 лет. Основной график списания судов (см. рис. 7 и 8) имеет после 2009 года ярко выраженный экспоненциальный характер, пик пришелся на 2013 год, когда было списано сразу 5 судов, утилизация продолжается. В отстое находится 8 судов средним возрастом 37 лет - они, скорее всего, также будут сданы на металлолом, причем именно по не востребованности на рынке.

Прямо противоположная тенденция наблюдается по сухогрузным судам типа «Омский / Орель» (строились в России и в Румынии в 1972-1995 годах), особенностью которых является возможность перевезти 3000 тонн груза при осадке в реке 3,20 м, что крайне важно для маловодных годов. Из 138 сухогрузов этого типа списано всего $13 \%$ - 18, причем 8 были потеряны в катастрофах, а сданы на металлолом всего 10 (см. рис. 9 и 10). В эксплуатации сейчас находятся 115 судов со средним возрастом 36,1 года, в отстое - 5 средним возрастом 39 лет (в основном, из-за банкротства операторов).

Безусловно, суда «Волго-Дон макс» класса востребованы еще больше, чем суда типа «Омский / Орель». Например, по сухогрузным судам типа «Волжский» проекта 05074 (строились в 1981-1999 годах). Из 63 сухогрузов этого типа 2 были потеряны в катастрофах, а 7 были переделаны в танкера. В эксплуатации сейчас находятся 50 судов средним возрастом 30,5 года, в отстое - 4 средним возрастом 29,8 года (в основном, из-за банкротства операторов).

По сухогрузным судам типа «Волго-Дон» проекта 1565 (строились в 1968-1990 годах). Из 108 сухогрузов этого типа списано 20\% - 22, причем 5 были потеряны в катастрофах, а сданы на металлолом 17 средним возрастом 37,6 года. В эксплуатации сейчас находятся 70 судов средним возрастом 42,4 года, в отстое 16 средним возрастом 44,5 года (см. рис. 11 и 12).

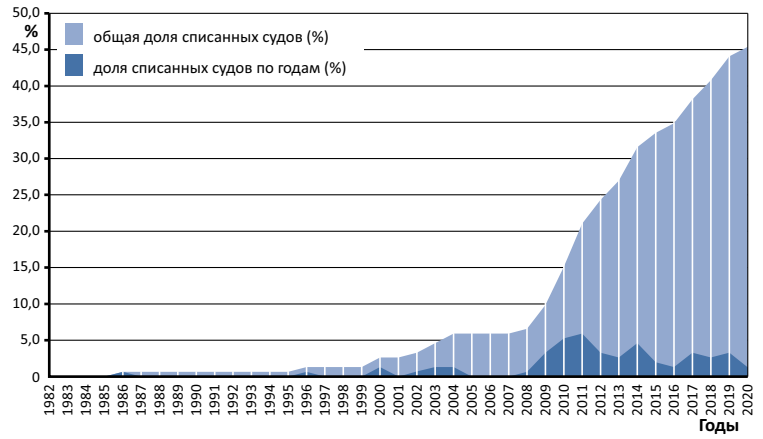

Рис. 3. Количество списанных судов в \% соотношении от всех судов типа «Волго-Балт»

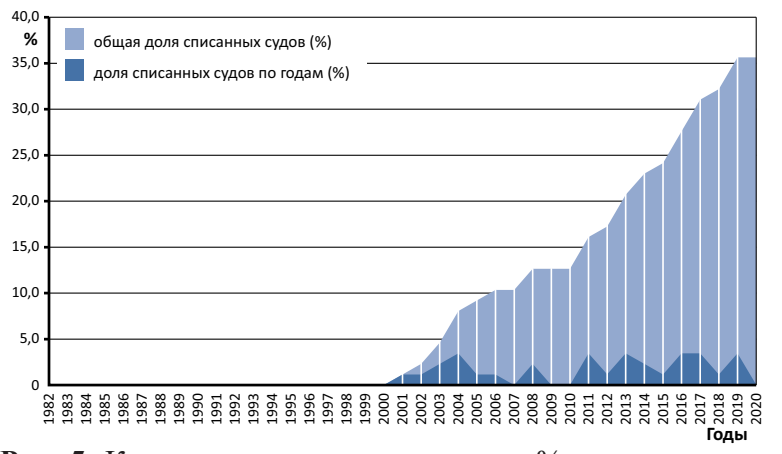

Рис. 5. Количество списанных судов в \% соотношении от всех судов проектов 19620, Р-168, 191 типа «СТ / Днепровец»

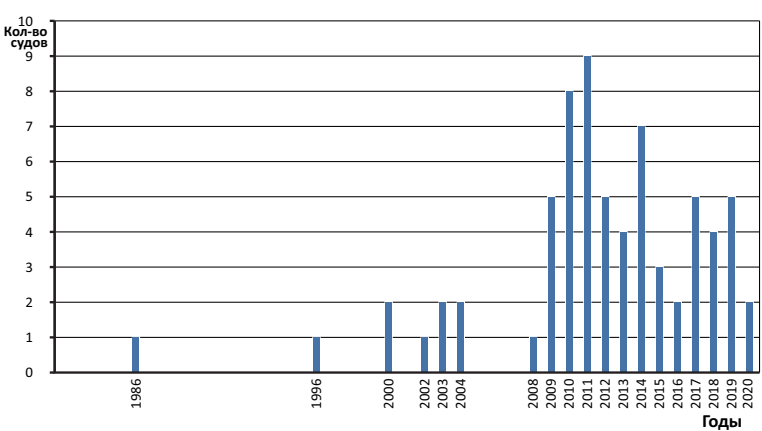

Рис. 4. Количество утилизированных судов проектов 2-95 и 2-95A/R с распределением по годам

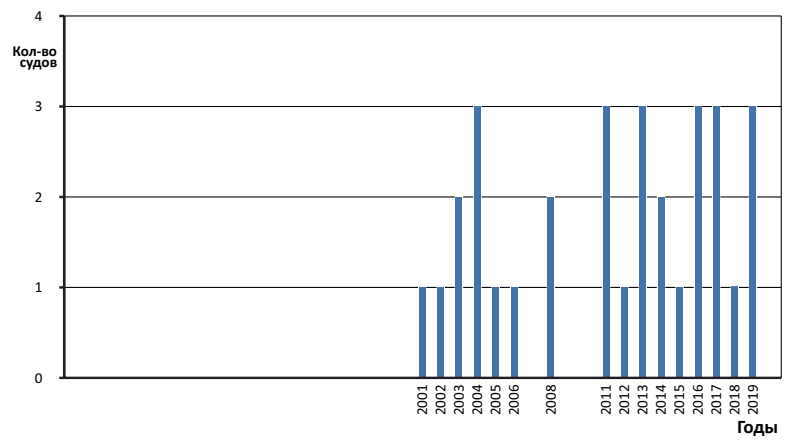

Рис. 6. Количество утилизированных судов проектов 19620 , P-168, 191 типа «СТ / Днепровец» с распределением по годам 


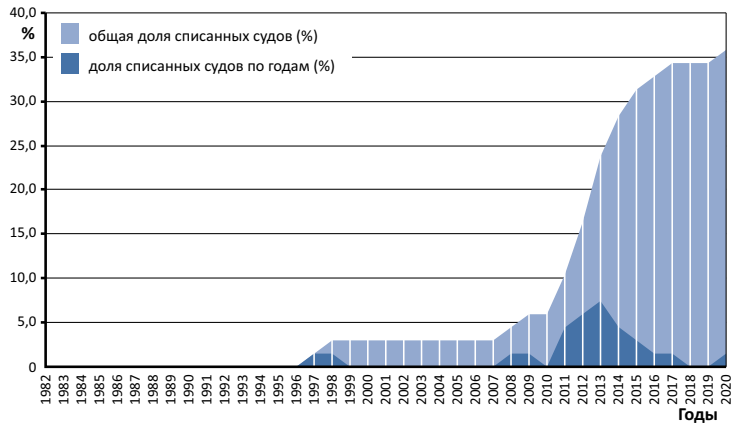

Рис. 7. Количество списанных судов в \% соотношении от всех судов проектов 326 и 326.1 типа «СТК / Таврия»

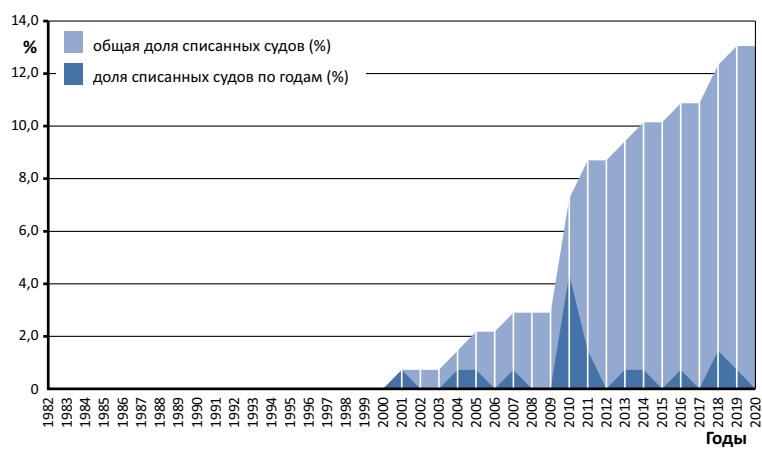

Рис. 9. Количество списанных судов в \% соотношении от всех судов типа «Омский / Орель»

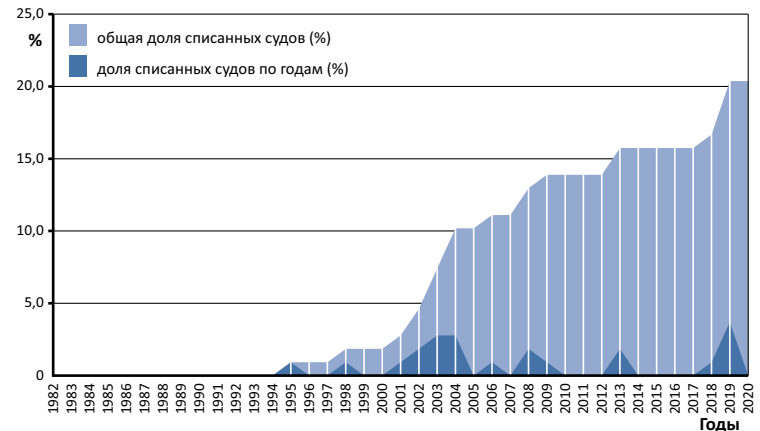

Рис. 11. Количество списанных судов в \% соотношении от всех судов проекта 1565 типа «Волго-Дон»

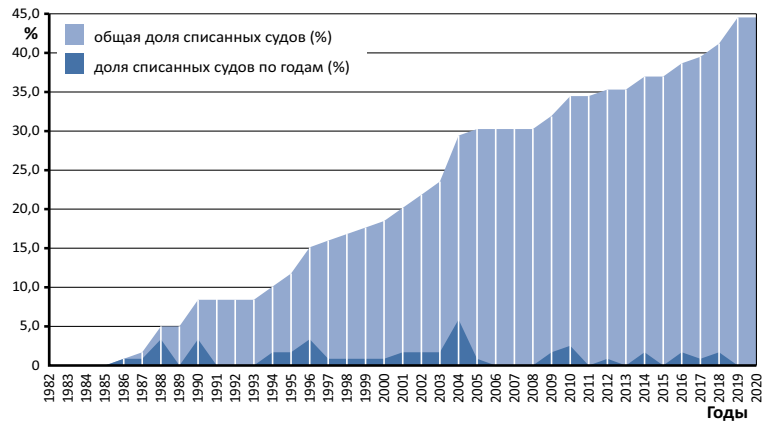

Рис. 13. Количество списанных судов в \% соотношении от всех судов проектов 507, 507А, 507Б типа «Волго-Дон»

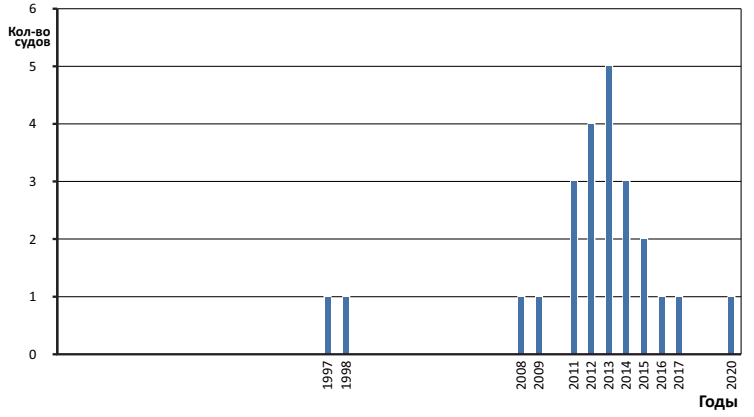

Рис. 8. Количество утилизированных судов проектов 326 и 326.1 типа «СТК / Таврия» с распределением по годам

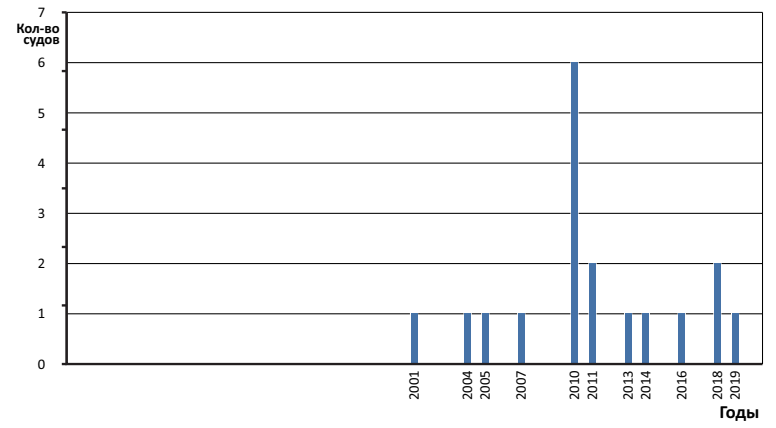

Рис. 10. Количество утилизированных судов типа «Омский / Орель» с распределением по годам

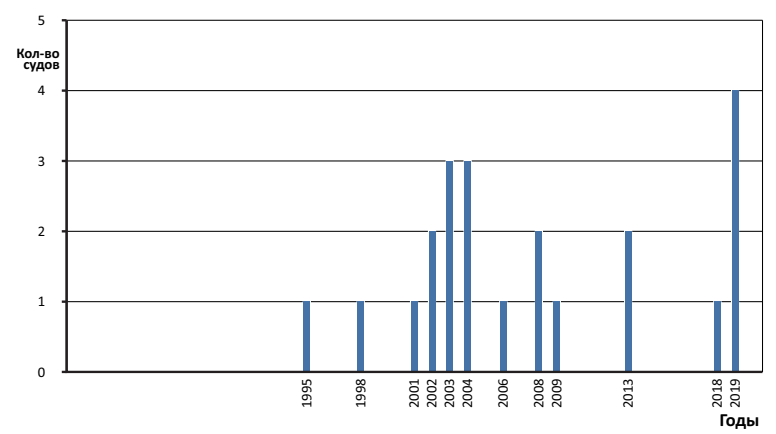

Рис. 12. Количество утилизированных судов проекта 1565 типа «Волго-Дон» с распределением по годам

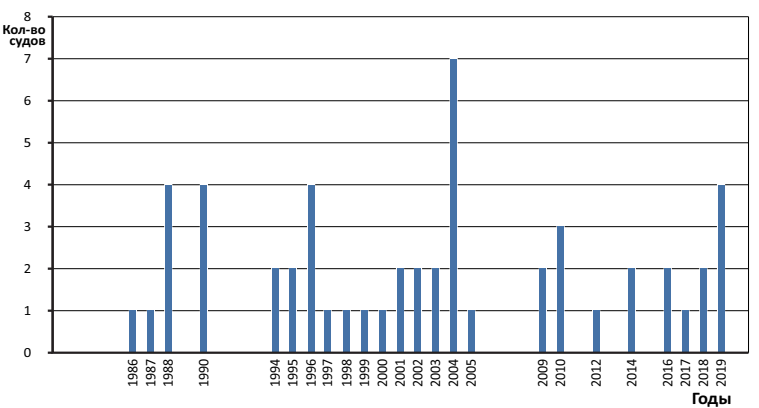

Рис. 14. Количество утилизированных судов проектов 507 , 507А, 507Б типа «Волго-Дон» с распределением по годам 


\section{СУДНОБУДУВАННЯ № 3- 2020}

Из 119 сухогрузных суден типа «Волго-Дон» проекта 507, 507А, 507Б (строились в 1960-1980 годах) списано 45\% - 53, причем 4 были потеряны в катастрофах, а сданы на металлолом 49 средним возрастом 37 лет. В эксплуатации сейчас находятся 53 судна со средним возрастом 45,6 года, в отстое - 13 средним возрастом 46 лет.
Основной график списания судов типа «ВолгоДон» имеет линейный характер (см. рис. 13 и 14). Суда сейчас работают, как правило, на реке, что, собственно, видно из графика списания, характерного для судов внутреннего плавания.

Прогнозировать выбытие судов смешанного рекаморе плавания можно в целом для всего флота, но это

Таблица 2. Прогноз выбытия сухогрузных судов смешанного река-море плавания «классических» проектов на апрель 2020 года

\begin{tabular}{|c|c|c|c|c|c|}
\hline Проект & $\begin{array}{c}\text { Прогноз } \\
\text { выбытия, год }\end{array}$ & $\begin{array}{c}\text { Кол-во судов } \\
2019 \text { г., ед. }\end{array}$ & $\begin{array}{c}\text { Кол-во судов } \\
2020 \text { г., ед. }\end{array}$ & $\begin{array}{c}\text { Прогноз кол-ва } \\
\text { судов на } 2025 \text { г., ед. }\end{array}$ & $\begin{array}{c}\text { Прогноз кол-ва } \\
\text { судов на } 2030 \text { г., ед }\end{array}$ \\
\hline \multicolumn{6}{|c|}{ «Волго-Дон максы» } \\
\hline $507 \mathrm{~A}, \mathrm{~B}$ & 2031 & 53 & 53 & 34 & 8 \\
\hline 1565 & 2034 & 81 & 70 & 61 & 31 \\
\hline 05074* & 2036 & 46 & 50 & 40 & 27 \\
\hline 19610,19611 & 2036 & 43 & 43 & 35 & 27 \\
\hline \multicolumn{2}{|c|}{ Итого по разделу } & 223 & 216 & 170 & 93 \\
\hline \multicolumn{6}{|c|}{ «Трехтысячники» } \\
\hline $92-040$ & 2033 & 32 & 34 & 25 & 5 \\
\hline 791 & 2022 & 3 & 3 & 0 & 0 \\
\hline $2-95$ & 2030 & 86 & 79 & 55 & 4 \\
\hline 1557 & 2029 & 50 & 47 & 18 & 0 \\
\hline 488 & 2033 & 33 & 34 & 25 & 17 \\
\hline $1743,1743.1$ & 2032 & 116 & 115 & 86 & 40 \\
\hline 16290,16291 & 2034 & 10 & 10 & 7 & 4 \\
\hline 292,0225 & 2031 & 30 & 30 & 25 & 7 \\
\hline 17310 & 2038 & 8 & 8 & 8 & 7 \\
\hline \multicolumn{2}{|c|}{ Итого по разделу } & 368 & 360 & 249 & 84 \\
\hline \multicolumn{6}{|c|}{ «Первые» серии } \\
\hline $21-88,21-89$ & 2031 & 53 & 47 & 29 & 4 \\
\hline 576 & 2028 & 51 & 50 & 20 & 0 \\
\hline Фин1000 & 2030 & 14 & 14 & 10 & 4 \\
\hline \multicolumn{2}{|c|}{ Итого по разделу } & 118 & 111 & 59 & 8 \\
\hline \multicolumn{6}{|c|}{ Морские ограниченного района плавания } \\
\hline 1588 & 2022 & 3 & 3 & 0 & 0 \\
\hline 16510 & 2035 & 3 & 3 & 3 & 2 \\
\hline 1572 & 2023 & 3 & 3 & 0 & 0 \\
\hline \multicolumn{2}{|c|}{ Итого по разделу } & 9 & 9 & 3 & 2 \\
\hline \multicolumn{6}{|c|}{ «Двухтысячники» } \\
\hline 613,620 & 2027 & 8 & 8 & 2 & 0 \\
\hline $781,781 Э$ & 2023 & 5 & 4 & 0 & 0 \\
\hline $285,289,787$ & 2025 & 8 & 3 & 1 & 0 \\
\hline \multicolumn{2}{|c|}{ Итого по разделу } & 21 & 15 & 3 & 0 \\
\hline \multicolumn{6}{|c|}{ СТ и СТК } \\
\hline 037 & 2022 & 1 & 1 & 0 & 0 \\
\hline $326,326.1$ & 2029 & 38 & 35 & 16 & 0 \\
\hline $\begin{array}{c}\text { 191, P-168, 19620, } \\
19621\end{array}$ & 2030 & 42 & 41 & 19 & 3 \\
\hline \multicolumn{2}{|c|}{ Итого по разделу } & 81 & 77 & 35 & 3 \\
\hline \multicolumn{6}{|c|}{ Площадки и бункерные без крышек } \\
\hline Д-080, Д-080МК & 2025 & 7 & 7 & 3 & 0 \\
\hline $\begin{array}{c}\text { P-32, P-32A, } \\
\text { P-32K }\end{array}$ & 2035 & 36 & 36 & 30 & 18 \\
\hline \multicolumn{2}{|c|}{ Итого по разделу } & 43 & 43 & 33 & 18 \\
\hline \multicolumn{2}{|c|}{ Итого по сухогрузным судам } & 863 & 831 & 552 & 208 \\
\hline
\end{tabular}


будет очень грубой оценкой, так как закономерности выбытия для судов различных проектов значительно отличаются друг от друга.

Для каждого проекта, базируясь на данных, полученных выше, и опираясь на выбранную модель утилизации, были получены сроки списания (без учета влияния конвенции BWM 2004), которые указаны в таблице 2.

Прогноз Морского Инженерного Бюро, основанный на полученных законах списания, -552 судов из «советских» серий останется в 2025 году, 208 судов в 2030 году.

Только в 2017 году было списано 30 сухогрузов, в 2018 году - 23, в 2019 году - 26, в 2020 году 5 (неполные данные). Среди списанных судов продолжают превалировать «трехтысячники» - 21 судно проекта 1557 типа «Сормовский», 18 судов проектов 2-95, 2-95A/R и 791 типа «Волго-Балт», 3 судна проекта 92-040 типа «Амур / Днепр», а также 9 судов типа «СТ / Днепровец» и «СТК / Таврия» (см. таблицу 3).

Таблица 3. Динамика состояния флота сухогрузных судов за 2018-2019 годы

\begin{tabular}{|c|c|c|c|c|c|c|c|c|c|c|c|c|}
\hline \multirow[b]{2}{*}{ Проект } & \multicolumn{4}{|c|}{ Всего списано } & \multicolumn{4}{|c|}{ Всего в отстое } & \multicolumn{4}{|c|}{ Всего в эксплуатации } \\
\hline & $\begin{array}{c}\text { на } \\
2018\end{array}$ & $\begin{array}{c}\text { на } \\
2019\end{array}$ & ед. & $\%$ & $\begin{array}{c}\text { на } \\
2018\end{array}$ & $\begin{array}{c}\text { на } \\
2019 \\
\end{array}$ & ед. & $\%$ & $\begin{array}{c}\text { на } \\
2018\end{array}$ & $\begin{array}{c}\text { Ha } \\
2019\end{array}$ & ед. & $\%$ \\
\hline \multicolumn{13}{|c|}{ «Волго-Дон максы» } \\
\hline $507 \mathrm{~A}, \mathrm{~B}$ & 49 & 53 & 4 & 8,2 & 17 & 13 & -4 & $-23,5$ & 53 & 53 & 0 & 0,0 \\
\hline 1565 & 19 & 22 & 3 & 15,8 & 8 & 16 & 8 & 100,0 & 81 & 70 & -11 & $-13,6$ \\
\hline 05074* & 12 & 9 & -3 & $-25,0$ & 5 & 4 & -1 & $-20,0$ & 46 & 50 & 4 & 8,7 \\
\hline 19610,19611 & 0 & 0 & 0 & 0,0 & 4 & 4 & 0 & 0,0 & 43 & 43 & 0 & 0,0 \\
\hline Итого по разделу & 80 & 84 & 4 & 5 & 34 & 37 & 3 & 8,82 & 223 & 216 & -7 & $-3,14$ \\
\hline \multicolumn{13}{|c|}{ «Трехтысячники» } \\
\hline $92-040$ & 5 & 6 & 1 & 20,0 & 7 & 4 & -3 & $-42,9$ & 32 & 34 & 2 & 6,3 \\
\hline 791 & 37 & 37 & 0 & 0,0 & 0 & 0 & 0 & 0,0 & 3 & 3 & 0 & 0,0 \\
\hline $2-95$ & 64 & 69 & 5 & 7,8 & 2 & 4 & 2 & 100,0 & 86 & 79 & -7 & $-8,1$ \\
\hline 1557 & 60 & 66 & 6 & 10,0 & 11 & 8 & -3 & $-27,3$ & 50 & 47 & -3 & $-6,0$ \\
\hline 488 & 0 & 0 & 0 & 0,0 & 1 & 0 & -1 & $-100,0$ & 33 & 34 & 1 & 3,0 \\
\hline $1743,1743.1$ & 18 & 18 & 0 & 0,0 & 4 & 5 & 1 & 25,0 & 116 & 115 & -1 & $-0,9$ \\
\hline 16290,16291 & 0 & 0 & 0 & 0,0 & 0 & 0 & 0 & 0,0 & 10 & 10 & 0 & 0,0 \\
\hline 292,0225 & 2 & 2 & 0 & 0,0 & 1 & 1 & 0 & 0,0 & 30 & 30 & 0 & 0,0 \\
\hline 17310 & 0 & 0 & 0 & 0,0 & 0 & 0 & 0 & 0,0 & 8 & 8 & 0 & 0,0 \\
\hline Итого по разделу & 186 & 198 & 12 & 6,45 & 26 & 22 & -4 & $-15,38$ & 368 & 360 & -8 & $-2,17$ \\
\hline \multicolumn{13}{|c|}{ «Первые» серии } \\
\hline $21-88,21-89$ & 57 & 58 & 1 & 1,8 & 8 & 13 & 5 & 62,5 & 53 & 47 & -6 & $-11,3$ \\
\hline 576 & 178 & 180 & 2 & 1,1 & 23 & 22 & -1 & $-4,3$ & 51 & 50 & -1 & $-2,0$ \\
\hline Фин 1000 & 5 & 5 & 0 & 0,0 & 1 & 1 & 0 & 0,0 & 14 & 14 & 0 & 0,0 \\
\hline Итого по разделу & 240 & 243 & 3 & 1,25 & 32 & 36 & 4 & 12,5 & 118 & 111 & -7 & $-5,93$ \\
\hline \multicolumn{13}{|c|}{ Морские ограниченного района плавания } \\
\hline 1588 & 21 & 21 & 0 & 0,0 & 0 & 0 & 0 & 0,0 & 3 & 3 & 0 & 0,0 \\
\hline 16510 & 0 & 0 & 0 & 0,0 & 0 & 0 & 0 & 0,0 & 3 & 3 & 0 & 0,0 \\
\hline 1572 & 23 & 24 & 1 & 4,3 & 9 & 8 & -1 & $-11,1$ & 3 & 3 & 0 & 0,0 \\
\hline Итого по разделу & 44 & 45 & 1 & 2,27 & 9 & 8 & -1 & $-11,11$ & 9 & 9 & 0 & 0 \\
\hline \multicolumn{13}{|c|}{ «Двухтысячники» } \\
\hline 613,620 & 6 & 7 & 1 & 16,7 & 2 & 1 & -1 & $-50,0$ & 8 & 8 & 0 & 0,0 \\
\hline $781,781 Э$ & 70 & 70 & 0 & 0,0 & 1 & 2 & 1 & 100,0 & 5 & 4 & -1 & $-20,0$ \\
\hline $285,289,787$ & 17 & 20 & 3 & 17,6 & 2 & 4 & 2 & 100,0 & 8 & 3 & -5 & $-62,5$ \\
\hline 1810двт, 1814двт & 20 & 20 & 0 & 0,0 & 2 & 2 & 0 & 0,0 & 0 & 0 & 0 & 0,0 \\
\hline Итого по разделу & 113 & 117 & 4 & 3,54 & 7 & 9 & 3 & 42,86 & 21 & 15 & -6 & $-28,57$ \\
\hline \multicolumn{13}{|c|}{ СТ и СТК } \\
\hline 037 & 8 & 8 & 0 & 0,0 & 0 & 0 & 0 & 0,0 & 1 & 1 & 0 & 0,0 \\
\hline $326,326.1$ & 23 & 24 & 1 & 4,3 & 6 & 8 & 2 & 33,3 & 38 & 35 & -3 & $-7,9$ \\
\hline 191, P-168, 19620, 19621 & 28 & 31 & 3 & 10,7 & 17 & 15 & -2 & $-11,8$ & 42 & 41 & -1 & $-2,4$ \\
\hline Итого по разделу & 59 & 63 & 4 & 6,78 & 23 & 23 & 0 & 0 & 81 & 77 & -4 & $-4,94$ \\
\hline \multicolumn{13}{|c|}{ Площадки и бункерные без крышек } \\
\hline Д-080, Д-080МК & 12 & 12 & 0 & 0,0 & 3 & 3 & 0 & 0,0 & 7 & 7 & 0 & 0,0 \\
\hline $\mathrm{P}-32, \mathrm{P}-32 \mathrm{~A}, \mathrm{P}-32 \mathrm{~K}$ & 4 & 4 & 0 & 0,0 & 0 & 0 & 0 & 0,0 & 36 & 36 & 0 & 0,0 \\
\hline Итого по разделу & 16 & 16 & 0 & 0 & 3 & 3 & 0 & 0 & 43 & 43 & 0 & 0 \\
\hline $\begin{array}{c}\text { Итого по сухогрузным } \\
\text { судам }\end{array}$ & 738 & 766 & 28 & $3,8 \%$ & 134 & 138 & 4 & $3,0 \%$ & 863 & 831 & -32 & $-3,7 \%$ \\
\hline
\end{tabular}


Также за последние три года списаны 12 судов проектов 507 и 1565 типа «Волго-Дон» (и поставлены на утилизацию еще 17 единиц) и три судна проекта 1743 типа «Омский / Орель», по более ранним оценкам, относящиеся к объектам, которые будут ремонтировать «до последнего», что является признаком физического старения корпуса и механизмов, так как сам тип таких судов востребован на рынке.

Сегодня в работе примерно 1052 сухогрузов, из них «старых» 79\%, остальные 21\% построены в XXI веке. При этом действующий грузовой флот это не только «советские» серии судов. С 2000 года построены (или куплены на рынке) 221 сухогрузное судно смешанного, внутреннего и морского ограниченного района плавания (поступало в среднем по 10 новых сухогрузов в год - см. таблицу 4).

Интересно, что 15 судов приобретены, а не специально заказаны под российские путевые условия. Причем китайской постройки три судна, голландской - пять, болгарской - четыре, немецкой - два, польской - один. Данные приведены без учета специально построенных в Китае для СЗП коастеров концепта DCV36 (10 судов) и ряда подобных проектов.

С 2000 года в России было построено 113 сухогрузных судов (51\%), в Китае - 32, в Украине и Турции по 21, в Румынии - 14, во Вьетнаме - 8 (см. рис. 15). С 2017 года количество поступавших от промышлен- ности новых сухогрузных судов превысило соответствующие поставки танкеров. Сейчас в постройке на разных стадиях находятся еще 59 сухогрузов. В России - 48 или $81 \%$ от общего заказа, в Китае и Украине - соответственно, по 4, в Турции - 3 .

Сейчас наиболее востребованными являются суда «Волго-Дон / Днепро макс» класса [2] - суда, отвечающие габаритам Волго-Донского судоходного канала (ВДСК) и Днепра и предназначенные для замены известных советских серий «Волго-Донов», т.е. универсальные по своим размерам суда для работы на европейской части внутренних водных путей с дедвейтом в реке от 4600 до 5400 тонн, в море - до 8000 тонн.

Их построено с 2000 года 71 единиц (32\%), но при этом среди заказанных их уже 55 , или $93 \%$.

Британское Королевское общество корабельных инженеров RINA в число лучших судов года в мире в 2018 году включило судно «Волго-Дон макс» класса «Пола Макария» проекта RSD59 - первое сухогрузное судно со «сверхполными» обводами [6;7]. На начало августа 2020 года в эксплуатации находятся уже 22 таких судна, еще 28 строится, а всего заказано 60 судов этого проекта. Проработана версия проекта RSD59 на газомоторном топливе (см. рис. 16).

Сопоставление технико-эксплуатационных характеристик проекта RSD59 с соответствующими

Таблица 4. Сводная статистика по новым сухогрузным судам за период 2000-2019 годы с прогнозом до 2022 года. Получено 221 судно и строится еще 59 судов

\begin{tabular}{|c|c|c|c|c|c|c|c|c|c|c|c|c|c|c|c|c|c|c|c|c|c|c|c|c|}
\hline \multirow[b]{2}{*}{ Проект } & \multicolumn{20}{|c|}{ Количество построенных судов } & \multicolumn{3}{|c|}{ Прогноз } & \multirow[b]{2}{*}{$\begin{array}{l}\text { Построено + } \\
\text { в постройке }\end{array}$} \\
\hline & ڤ్రి & ర్స్ & ర్లి & ڤ్సి & હે & ڤ్ & ఫ్రి & 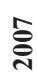 & ڤ్ సે & હેे & ิㅗำ & $\bar{\Xi}$ & 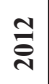 & હે & $\stackrel{\Xi}{\bar{N}}$ & 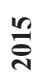 & ํㅗㄱ & 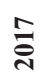 & 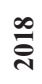 & $\hat{\bar{N}}$ & ָิ઼ & $\overline{\widetilde{\vartheta}}$ & ָิ & \\
\hline $\begin{array}{c}\text { Сухогрузные } \\
\text { суда «Волго- } \\
\text { Дон макс» } \\
\text { / «Днепро } \\
\text { макс» класса }\end{array}$ & 2 & 1 & 1 & & 2 & 3 & 4 & 6 & 4 & 3 & 1 & 9 & 5 & 6 & 3 & & 2 & 3 & 6 & 10 & 18 & 26 & 11 & $\begin{array}{c}71+55 \\
\text { Россия } 54+47, \\
\text { Украина } 11+4 \\
\text { Китай } 4+3, \\
\text { Турция } 2+1\end{array}$ \\
\hline $\begin{array}{c}\text { Сухогрузные } \\
\text { суда других } \\
\text { классов }\end{array}$ & 4 & 3 & 5 & 8 & 6 & 9 & 15 & 17 & 9 & 6 & 6 & 7 & 11 & 4 & 2 & 1 & & 15 & 12 & 9 & 2 & 2 & & $\begin{array}{c}150+4 \\
\text { Россия } 59+1, \\
\text { Китай } 28+1, \\
\text { Турция } 19+2, \\
\text { Румыния } 14, \\
\text { Украина 10, } \\
\text { Вьетнам } 8, \\
\text { Нидерланды } 5, \\
\text { Болгария 4, } \\
\text { Германия 2, Польша } 1\end{array}$ \\
\hline $\begin{array}{c}\text { Всего } \\
\text { сухогрузных } \\
\text { судов }\end{array}$ & 6 & 4 & 6 & 8 & 8 & 12 & 19 & 23 & 13 & 9 & 7 & 16 & 16 & 10 & 5 & 1 & 2 & 18 & 18 & 19 & 20 & 28 & 11 & $\begin{array}{c}221+59 \\
\text { Россия } 113+48, \\
\text { Китай } 32+4, \\
\text { Украина } 21+4, \\
\text { Турция } 21+3, \\
\text { Румыния } 14, \\
\text { Вьетнам } 8, \\
\text { Нидерланды } 5, \\
\text { Болгария 4, } \\
\text { Германия 2, Польша } 1\end{array}$ \\
\hline
\end{tabular}

Источник: Морское Инженерное Бюро 


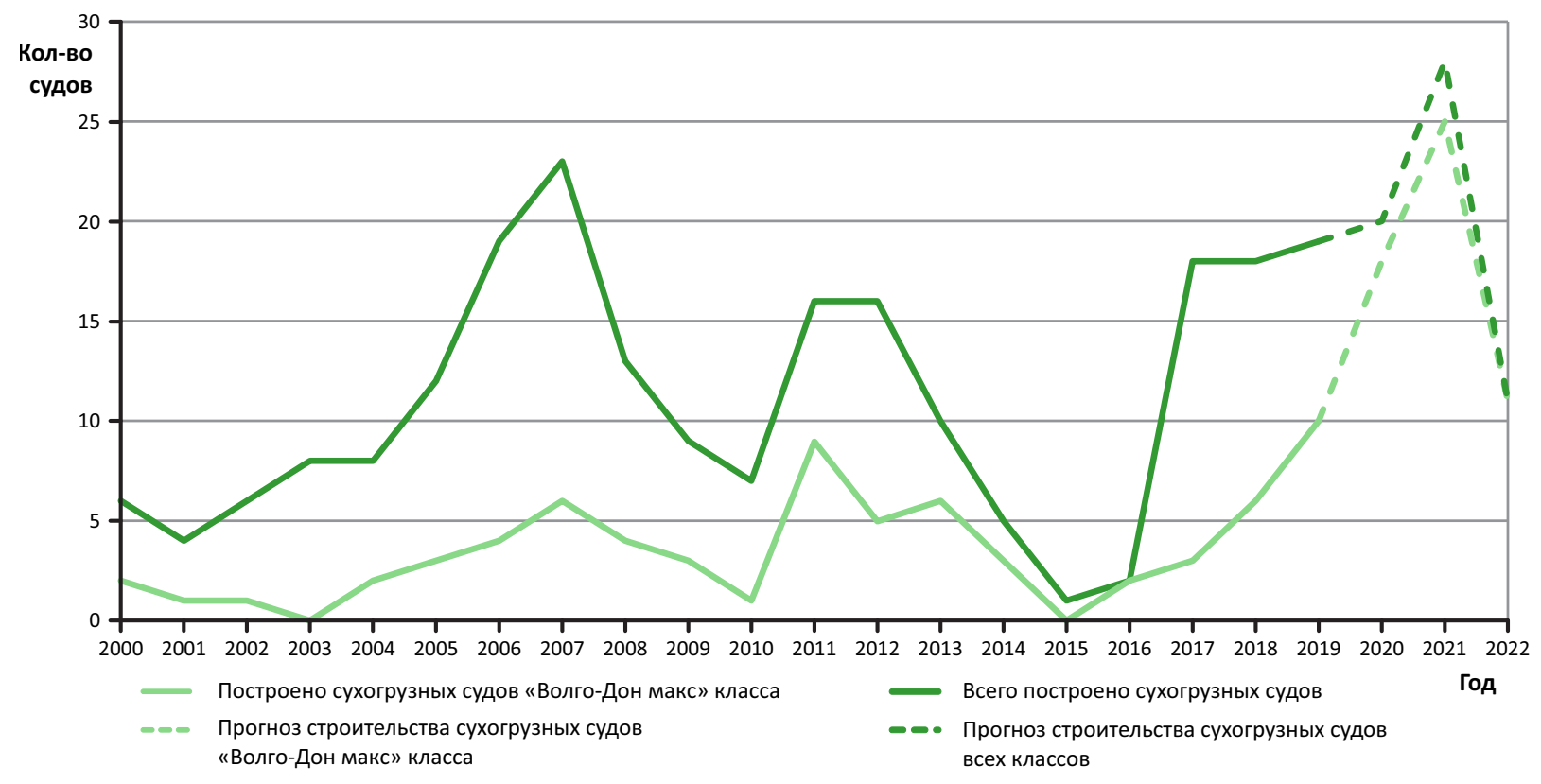

Рис. 15. График постройки новых сухогрузных судов
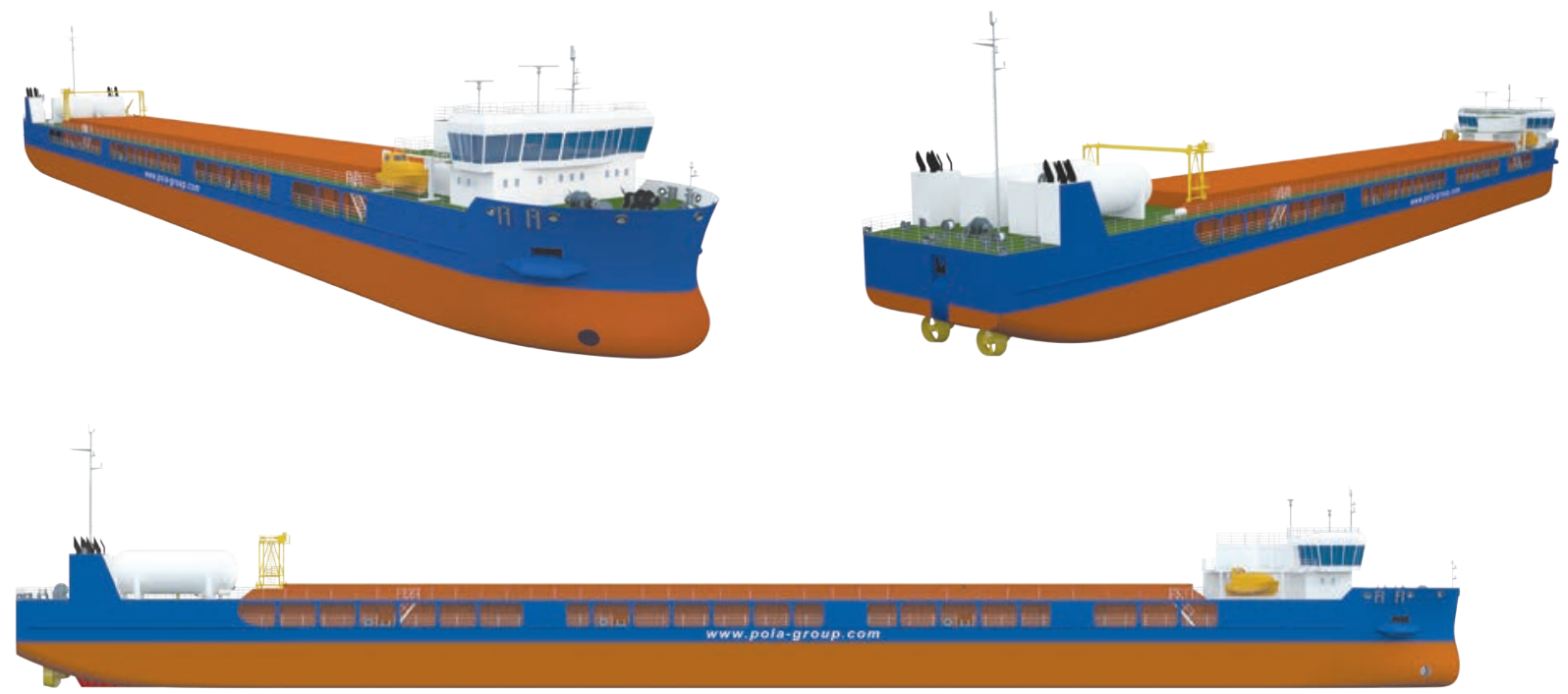

Рис. 16. Общий вид сухогрузного судна проекта RSD59 на газомоторном топливе

характеристиками судов класса «Волго-Дон/ Днепро макс» показывает, что новый концепт по энергозатратам на единицу транспортной производительности лучше, чем проекты RSD49 и 006RSD05, выполненные на основе популярных в начале XXI века обводов «Армад», и заметно лучше, чем сухогрузные суда типа «Волга» и «Русич».

Если к этому добавить и существенный рост абсолютного значения дедвейта (и с ним коэффициента утилизации дедвейта по водоизмещению), причем как на полной осадке, так, что еще более весомо, в реке (прибавка от 800 тонн в сравнении с «Невой-Лидером» и до 1495 тонн в сравнении с «Волгой»), при примерно одинаковых массе порожнем и пакете оборудования, то преимущество нового концепта RSD59 типа «Пола Макария» становится подавляющим.

Однако следует понимать, что речь идет именно о философии «сверхполного» судна, а не о деталях, так как вряд ли стоит всем строить только двухтрюмные суда с длинным 80-метровым трюмом, классом РC, который необходим для работы вокруг Европы. Вероятно, зерновая грузовая база требует суда 


\section{СУДНОБУДУВАННЯ № 3 - 2020}

в таких же «сверхполных» обводах и с сохранением наиболее сложных частей судна (корма, машинное отделение, надстройка, новая оконечность), но с более легкими корпусами и меньшей высотой борта в средней части. Это даст добавку примерно 200 тонн груза на осадках от 3,60 до 4,00 м (развитие проекта RSD59 - концепт RSD62), с привычным количеством трюмов - 3-4, как сделано, например, на RSD79, возможно с люковыми закрытиями иного типа (фолдинг, пиги-бег).

Кроме того, отмечается значительный интерес средних и малых судовладельцев к судам взамен «Омских» проекта RSD34, но для «запуска» таких серий требуется следующий шаг, а именно операционный лизинг.

Наконец, Волжское пароходство уже практически десять лет успешно эксплуатирует десять новых сухогрузных судов проекта RSD44 типа «Герои Сталинграда», в том числе на РПК рейда морского порта Кавказ в классе «М-ПР». Дедвейт судна проекта RSD44 при осадке 3,60 м в реке выше примерно на 100 тонн, чем y RSD59, а стоимость в постройке меньше (они легче по массе и проще по требованиям класса).

Надводный габарит в балласте RSD44 составляет всего 5,4 м (в грузу еще меньше), что позволит ему, в отличие от всех остальных, проходить под мостами через реку Неву, под Ростовским железнодорожным мостом без их разводки. В результате судно будет экономить время на ожидание очереди в разводку мостов, которое составляет до 20 суток за навигацию.

В целом востребованные на современном рынке транспортных услуг классы сухогрузных судов смешанного и ограниченного района плавания приведены в таблице 5 .

Совершенно иная ситуация в Сибири, на севере европейской части. Причем рассматривать вопрос о пополнении флота северных рек необходимо, исходя из имеющихся в наличии и перспективных грузопотоков конкретного региона, его народнохозяйственных потребностей. Соответственно, проекты судов нового поколения будут для Дальнего Востока и Сибири отличаться от концептов европейской части.

При ограниченных габаритах судов и глубинах увеличение грузоподъемности возможно только за счет увеличения общей полноты и снижения массы судна порожнем.

«Сверхполные» обводы, которыми сегодня оперирует на RSD59, RSD62, RSD79 Морское Инженерное Бюро, являются вполне окончательным ответом на первый вопрос, а по снижению массы корпуса из стали все попытки улучшить решения МИБ другими коллегами привели на чужих проектах лишь к обратному результату - росту металлоемкости - на какихто на 200 тонн, на каких-то на 300 тонн, а на некоторых проектах и более и соответствующему снижению грузоподъемности.
Таким образом, практически установлено, что уменьшить массу судна можно уже только за счет более легких материалов [3].

Алюминиевые сплавы, безусловно, широко известны в отечественном судостроении многие годы и применяются, в первую очередь, для корпусов скоростных судов (для увеличения полезной нагрузки за счет снижения массы корпуса), надстроек и рубок пассажирских судов, паромов и служебно-вспомогательных судов (для решения вопросов по остойчивости за счет снижения положения ЦТ по высоте). Примером могут служить надстройки круизных судов нового поколения проектов PV08, PV09, PV300, PV300VD.

Новшеством является применение новых Al-Mg сплавов с пониженным содержанием скандия, разработанных Русалом.

Основные преимущества деформируемых Sc-содержащих сплавов RUSAL (c 0,1\% Sc): низкая стоимость (в 2-3 раза) по сравнению с традиционными Sc-содержащими сплавами; по уровню прочностных свойств превосходит традиционные сплавы минимум на $40 \%$; высокий уровень свойств достигается без использования операции закалки в воду. Достигнуто снижение стоимости Sc сплавов (в виде слитков) до 5000 долларов США за тонну (при содержании до $0,1 \% \mathrm{Sc})$.

За счет роста прочности масса конструкций может быть снижена по сравнению с обычными алюминиевыми сплавами примерно на 25\%.

Поэтому особое внимание должно быть уделено применению алюминиевых сплавов для изготовления люковых закрытий речных сухогрузных судов. Для перспективного судна внутреннего плавания грузоподъемностью около 2500 тонн длиной 110 м и шириной 12 м масса такого люкового закрытия составит всего около 25 тонн.

НИЦ «Курчатовский институт - ЦНИИ КМ «Прометей» разработал технологию производства сварных крупногабаритных облегченных панелей (СКОпанелей) с использованием катаных и прессованных полуфабрикатов из коррозионностойких алюминиево-магниевых сплавов 1561,1565 толщиной от 2,5 мм методом сварки трением с перемешиванием.

Для грузовых судов смешанного река-море плавания и речного плавания актуальными является применение композитов для изготовления люковых закрытий (такое решение применяется повсеместно на водном транспорте США), перемещаемых поперечных переборок, дельных вещей, элементов надстройки.

Собственно говоря, именно то, что утилизация сухогрузных судов шла более быстрыми темпами, чем поступление новых и нехватка тоннажа для вывоза зерна на Юге, привело к резкому росту (на сегодня) заказов на новые сухогрузы. Однако в этом вопросе есть много важных нюансов. 
Таблица 5. Основные типоразмеры современных сухогрузных СОРП, востребованных на отечественном рынке

\begin{tabular}{|c|c|c|c|c|c|c|c|}
\hline $\begin{array}{c}\text { Отличительная } \\
\text { особенность } \\
\text { класса судна, } \\
\text { номер проекта } \\
\text { Морского Инже- } \\
\text { нерного Бюро }\end{array}$ & $\begin{array}{c}\text { Габаритные } \\
\text { длина х } \\
\text { ширина x } \\
\text { высота } \\
\text { борта, м }\end{array}$ & $\begin{array}{c}\text { Дедвейт при } \\
\text { максималь- } \\
\text { ной осадке, т }\end{array}$ & $\begin{array}{c}\text { Дедвейт при } \\
\text { осадке 3,60 м, } \\
\text { т (в реке) }\end{array}$ & $\begin{array}{c}\text { Размеры } \\
\text { трюмов, м } \\
(\text { (xbxh) }\end{array}$ & $p, \mathbf{T} / \mathbf{M}^{2}$ & $\begin{array}{c}\text { Вмести- } \\
\text { мость } \\
\text { трюмов, } \\
\mathbf{m}^{3}\end{array}$ & Класс Регистра \\
\hline \multicolumn{8}{|c|}{ «Волго-Дон / Днепро макс» класс } \\
\hline RSD59 & 141,00 r & $\begin{array}{c}8142 \\
(4,70 \mathrm{M}) \\
\end{array}$ & 5320 & 77,35 г & 12 & 11200 & $\begin{array}{c}\text { KM } \circledast \text { Ice2 R2 } \\
\text { AUT1-ICS }\end{array}$ \\
\hline RSD49 & 139,95 ז & $\begin{array}{c}7154 \\
(4,70 \mathrm{M})\end{array}$ & 4518 & 51,72 ז & 12 & 10920 & $\begin{array}{c}\mathrm{KM} \circledast \text { Ice2 R2 } \\
\text { AUT1-C }\end{array}$ \\
\hline RSD44 & 139,99ז & $\begin{array}{c}5562 \\
(3,53 \mathrm{M})\end{array}$ & 5543 & $49,8 \Gamma$ & 5,1 & 7090 & $\begin{array}{l}\text { М-ПР 2,5 } \\
\text { (лед 20) А }\end{array}$ \\
\hline \multicolumn{8}{|c|}{ Грузоподъемность около 5000 тонн при осадках 4,2-4,5 м, «Азовский пятитысячник» } \\
\hline RSD32M & 123,17 & $6328(4,745$ м) & 3940 & 27,30 r & 10 & 8804 & $\begin{array}{c}\mathrm{KM} \otimes \text { Ice1 R2 } \\
\text { AUT1-ICS }\end{array}$ \\
\hline \multicolumn{8}{|c|}{ Грузоподъемность около 3000 тонн при осадке 3,6 м, взамен «Омский» / «Волго-Балтов» / «Сормовских» } \\
\hline RSD34 & 109,10r & $\begin{array}{c}3600 \\
(3,53 \mathrm{M})\end{array}$ & 3600 & 20,35 г & 7,5 & 6446 & $\begin{array}{c}\mathrm{KM} \otimes \text { Ice1R2RS- } \\
\mathrm{N} 4,5 \mathrm{AUT} 1-\mathrm{ICS}\end{array}$ \\
\hline 005RSD03 & 108,33 ז & $\begin{array}{c}5499 \\
(4,792 \mathrm{M})\end{array}$ & 3340 & 21,45 г & 7,5 & 7833 & $\begin{array}{c}\text { КМ } \circledast \text { ЛУ2 } 1 \text { II } \\
\text { СП А } 3\end{array}$ \\
\hline RSD10 & 99,90 r & $\begin{array}{c}4505 \\
(4,80 \mathrm{M}) \\
\end{array}$ & 2690 & 32,5 г & 10 & 6000 & M \\
\hline \multicolumn{8}{|c|}{ Грузоподъемность около 3000 тонн при осадках 4,2-4,5 м, «Азовский трехтысячник» } \\
\hline 003RSD04 & 89,73 ז & $3756(4,461 \mathrm{м})$ & 2584 & 59,15 г & 7 & 4832 & 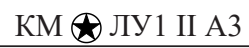 \\
\hline $\begin{array}{l}\text { 003RSD04/ } \\
\text { ALB03 }\end{array}$ & 89,17 r & $4416(5,286$ м) & 2243 & 59,00 r & 7 & 5486 & $\begin{array}{c}\text { KM } \circledast \text { Ice3 R1 } \\
\text { AUT3 }\end{array}$ \\
\hline RSD16 & 89,73 ז & $3152(4,50 \mathrm{M})$ & 2106 & 58,5 г & 10 & 4300 & 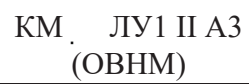 \\
\hline \multicolumn{8}{|c|}{ Европейские «коастеры», грузоподъемность около 5000-6000 тонн при осадке 5,5 м } \\
\hline DCV46 & 119,67 r & $\begin{array}{c}7443 \\
(6,11 \mathrm{M})\end{array}$ & $\begin{array}{c}4674 \\
(4,50 \mathrm{M})\end{array}$ & 56,0 г & 12 & 10111 & $\begin{array}{c}\text { Hull: } 100 \text { A5 E1 } \\
\text { G Multi-Purpose } \\
\text { Dry Cargo Ship, } \\
\text { SOLAS-II-2, } \\
\text { Reg.19, Equipped } \\
\text { for Carriage of } \\
\text { Containers, DBC } \\
\text { Machinery: MC } \\
\text { E1 AUT }\end{array}$ \\
\hline \multicolumn{8}{|c|}{ Европейские «коастеры» с конвенционной длиной до 85 м } \\
\hline DCV36 & $89,96 r$ & $\begin{array}{c}5026 \\
(6,40 \mathrm{M}) \\
\end{array}$ & $\begin{array}{c}2748 \\
(4,50 \mathrm{M})\end{array}$ & 60,0 г & 14 & 6228 & $\mathrm{KM} \oplus \mathrm{Ice} 3 \mathrm{AUT} 1$ \\
\hline DCV33 & 89,99 ז & $4509(5,812 \mathrm{M})$ & $\begin{array}{c}3019 \\
(4,50 \mathrm{M})\end{array}$ & 60,0 г & 12 & 5611 & 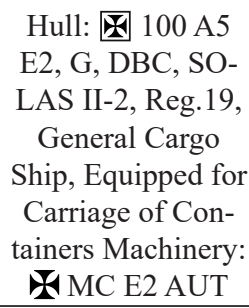 \\
\hline \multicolumn{8}{|c|}{ Малое накатное судно снабжения с возможностью высадки на необорудованный берег } \\
\hline DCV47 & 42,60 r & $264(2,175 \mathrm{M})$ & - & $25,2 \Gamma$ & 15 & $140 * *$ & $\begin{array}{c}\text { KM } \circledast \text { Ice2 } 1 \text { R } 1 \\
\text { AUT3 OMBO }\end{array}$ \\
\hline
\end{tabular}




\section{СУДНОБУДУВАННЯ № 3- 2020}

Во-первых, списание идет в основном судов грузоподъемностью 2000-3000 тонн, а вовсе не «Волго-Дон максов». А постройка происходит как раз в основном «Волго-Дон максов», грузоподъемность которых на осадках 3,60-4,20 м в 2-3 раза превышает грузоподъемность судов, которые они, по сути, меняют.

Во-вторых, ставки на перевозки сухих высокомаржинальных грузов очень изменчивы (особенно, если посмотреть достаточно длинный период). Ведь не случайно в 2010-2016 годах сухогрузные суда строились не столь активно, как танкеры, - просто ставки не позволяли.

Главной бедой воднотранспортной отрасли является проблема маловодности, которая, в свою очередь, приводит к недостаточным глубинам.

Следует понимать, что недогруз сухогруза «Волго-Дон / Днепро макс» класса на 60 см (т.е. вместо осадки 3,60 м - 3,00 м) приводит к потере грузоподъемности в 1180-1320 тонн.

А ведь именно с падения фактических загрузок танкеров при недостаточных глубинах началось снижение подачи нефтегрузов на реку с передачей этих объемов (заводы же продолжают работать) на железную дорогу.

Второй (по порядку, но не по значению) проблемой является неустойчивая грузовая база. Опять же ярким примером является резкое сокращение подачи нефтепродуктов к перевозке по реке - в 2015-2019 годах в два раза меньше, чем, например, в 2013 году. И все это происходило на фоне крайне незначительного списания старых танкеров и активного поступления новых судов. В результате заказ новых танкеров был вынужденно приостановлен (и это несмотря на средний возраст конкурирующих с новыми танкера типа «Волгонефть» в 43 года).

Вообще отдельный вопрос - существующий грузовой флот, который был построен с конца 1950-х годов до 2000 года по проектам «советского» типа. Это вполне хорошие и надежные суда, тем более они уже столько лет находятся в эксплуатации. Но когда было построено новых танкеров в 1,6 раза больше, чем списали старых, и это совпало с кризисом грузовой базы, то результатом было резкое падение доходности работы танкеров и их простоям.

\section{ОБСУЖДЕНИЕ ПОЛУЧЕННЫХ РЕЗУЛЬТАТОВ И ВЫВОДЫ}

Сегодня в работе примерно 1052 сухогрузов, из них «старых» 79\%, остальные $21 \%$ построены в XXI веке. С 2000 года построено (или куплено на рынке) 221 сухогрузное судно смешанного, внутреннего и морского ограниченного района плавания. По состоянию на апрель 2020 года, работает 831 сухогруз «советских» серий средним возрастом 39,8 года. Списано 766 судов (44\%), из них потеряно в катастрофах 95 (12\%) средним возрастом 31,2 года и утилизировано 671 средним возрастом сдачи на металлом 36,5 года. В отстое 138 судов со средним возрастом 44,2 года.

С 2017 года количество поступавших от промышленности новых сухогрузных судов превысило соответствующие поставки танкеров. Сейчас в постройке на разных стадиях находятся еще 59 сухогрузов.

Главным фактором, определяющим параметры грузовых судов водного транспорта, безусловно, является грузовая база. Именно грузопотоки определяют количество и тип требуемых судов.

Темпы постройки новых судов следует согласовывать с реальной грузовой базой и фактическим списанием старых судов-конкурентов.

Наиболее востребованными были и остаются сухогрузные суда «Волго-Дон / Днепро макс» класса - суда, отвечающие габаритам ВДСК и предназначенные для замены известных советских серий «Волго-Донов», т.е. универсальные по своим размерам суда для работы на европейской части внутренних водных путей.

При ограниченных габаритах судов и глубинах увеличение грузоподъемности возможно только за счет увеличения общей полноты и снижения массы судна порожнем.

«Сверхполные» обводы, которыми сегодня оперирует на RSD59, RSD62, RSD79 Морское Инженерное Бюро, являются вполне окончательным ответом на первый вопрос, а по снижению массы корпуса из стали все попытки улучшить решения МИБ другими коллегами привели на чужих проектах лишь к обратному результату - росту металлоемкости и соответствующему снижению грузоподъемности.

Таким образом, практически установлено, что уменьшить массу судна порожнем можно уже только за счет более легких материалов.

\section{REFERENCES}

[1] Egorov G. V. (2007). Proektirovaniye sudov ogranichennykh rayonov plavaniya na osnovanii teorii riska [Design of restricted area ships based on risk theory]. Sudostroenie, 384 p. (in Russian).

[2] Egorov G. V. (2011). Obnovlennaya lineyka mnogotselevykh sukhogruznykh sudov smeshannogo plavaniya i koasterov Morskogo Inzhenernogo Byuro [Updated line-up of multipurpose river-sea dry-cargo vessels and coasters]. Morskaya Birzha, No. 3 (37), pp. 38-42 (in Russian).

[3] Egorov G. V. (2019). Opyt i perspektivy primeneniya novykh konstruktsionnykh materialov v otechestvennom sudostroyenii [Experience and prospects of using of new structural materials in native shipbuilding]. Proc. of Int. sc.-pract. conf. in honor of Dr, Prof. O.M. Paliy. SPb: Krylov State Research Center (KSRC), pp. 127-128 [in Russian].

[4] Egorov G. V., Egorov A. G. (2017). Fakticheskoye spisaniye sudov smeshannogo reka-more plavaniya i prognoz utilizatsii sudov do 2025 goda. Tipy sudov, vostrebovannyye rynkom [Actual decommissioning of river-sea vessels and forecast of vessels utilization until 2025. Types of vessels demanded by the market]. Morskaya Birzha, No. 3 (61), pp. 30-36 (in Russian). 
[5] Egorov G. V., Tonyuk V. I. (2019). O proektirovanii sukhogruznykh sudov smeshannogo plavaniya proyekta RSD32M [About design of river-sea dry-cargo vessels of RSD32M project]. Proc. of Int. sc.-pract. conf. in honor of Dr, Prof. O.M. Paliy. SPb: KSRC, pp. 133-134 [in Russian].

[6] Egorov G. V., Tonyuk V. I., Durnev Ye. Yu. (2019). «Sverkhpolnoye» mnogotselevoye sukhogruznoye sudno proyekta RSD59 dlya vsekh vidov sukhikh gruzov ["Superfull” multipurpose dry-cargo vessel of RSD59 project for all types of dry cargoes]. Collection book of KSRC. Special volume 1. pp. 234-239 [in Russian].

[7] Egorov G. V., Tonyuk V. I., Egorov A. G., Davydov I. F. (2019). Justification of main characteristics of river-sea dry-cargo vessels with extra-full hull forms. Proc. of the $18^{\text {th }}$ Intern. Congress of IMAM (IMAM 2019) "Sustainable Development and Innovations in Marine Technologies”. Varna, Bulgaria. Pp. 332-337.

\section{СПИСОК ИСПОЛЬЗОВАННОЙ ЛИТЕРАТУРЫ}

[1] Егоров, Г. В. (2007). Проектирование судов ограниченных районов плавания на основании теории риска. Санкт-Петербург : Судостроение. 384 с.

[2] Егоров, Г. В. (2011). Обновленная линейка многоцелевых сухогрузных судов смешанного плавания и коастеров Морского Инженерного Бюро. Морская Биржа. № 3 (37). С. 38-42.

[3] Егоров, Г. В. (2019). Опыт и перспективы применения новых конструкционных материалов в отечественном судостроении. Труды НТК по СМК, посвященной памяти д.т.н., проф. О.М. Палия. Санкт-Петербург : Крыловский государственный научный центр (КГНЦ). С. 127-128.

[4] Егоров, Г. В., Егоров, А. Г. (2017). Фактическое списание судов смешанного река-море плавания и прогноз утилизации судов до 2025 года. Типы судов, востребованные рынком. Морская Биржа. № 3 (61). С. 30-36.

[5] Егоров, Г. В., Тонюк, В. И. (2019). О проектировании сухогрузных судов смешанного плавания проекта RSD32M. Труды НТК по СМК, посвященной памяти д.т.н., проф. О.М. Палия. Санкт-Петербург : КГНЦ. С. 133-134.

[6] Егоров, Г. В., Тонюк, В. И., Дурнев, Е. Ю. (2019). «Сверхполное» многоцелевое сухогрузное судно проекта RSD59 для всех видов сухих грузов. Труды КГНЦ. Спец. выпуск № 1. С. 234-239.

[7] Egorov, G. V., Tonyuk, V. I., Egorov, A. G., Davydov, I. F. (2019). Justification of main characteristics of river-sea dry-cargo vessels with extra-full hull forms. Proc. of the $18^{\text {th }}$ Intern. Congress of IMAM (IMAM 2019) "Sustainable Development and Innovations in Marine Technologies". Varna, Bulgaria. Pp. 332-337. 